\title{
Por que é básica a pesquisa básica
}

\author{
Fronando Dias de Avila-Pires
}

Discussões sobre a oportunidade e prioridade de se desenvolverem pesquisas básicas, isto é, aquelas que não anunciam uma perspectiva de aplicação imediata, giram freqüentemente em torno das restrições impostas pela limitação de recursos disponiveis e invocam a responsabilidade social do cientista. Argumentam, uns contra o alegado desperdicio de verbas, sempre escassas, em projetos cujos resultados terão mera importância teórica ou potencial, outros a favor da pesquisa acadêmica, que eventualmente revelará suas aplicações práticas, de modo inesperado, como tem mostrado a História.

Em primeiro lugar, é impossível distinguir o que seria uma pesquisa "pura": para um especialista é fácil apresentar justificativa para qualquer projeto, por mais abstruso que seja. De outro lado, não é difícil realizar investigações fundamentais dentro de qualquer tema "aplicado".

A implantação e o desenvolvimento de programas de apoio à chamada pesquisa "básica" impõe-se, na verdade, por razões que não aquelas sobejamente argumentadas.

A formação e amadurecimento de uma comunidade científica dentro da sociedade civil é indispensável, se a nação pretende tornar-se independente no sentido mais amplo do termo. O domínio do conhecimento não só é poder como é traduzivel em termos de riqueza econômica, uma vez que se institui em fonte potencial de tecnologia.

$\mathrm{Na}$ visão popular estereotipada, o pesquisador trabalha isolado, em segredo, emergindo de tempos em tempos de seu laboratório com uma teoria revolucionária e inovadora. A realidade é outra. No exercício profissional, a revolução científica representa uma fração da contribuição do cientista e é algo que ocorre raramente - se alguma vez - durante sua vida. $\mathrm{O}$ isolamento, comum ainda em muitas áreas, significa a escassez de colegas da mesma especialidade, com quem possa trocar idéias. Os contatos são mantidos através de correspondência e dos congressos e seminários, além do envio de publicações. A ciência é uma atividade social e corporativa, ainda que muitos indivíduos trabalhem solitários em suas instituições. Mas é sempre cxigido do pesquisador que ele se mantenha ao par do que se passa nos limites ou fronteiras do conhecimento $\mathrm{em}$ sua especialidade, e das instituições e autoridades mais produtivas e destacadas em sua área. Deve conhecer os paradigmas corretamente admitidos, seus pontos fracos, os problemas, métodos e a linguagem própria de sua disciplina.

Cadernos de Saúde Pública, R.J., 4(3): 505-506, out/dez, 1987. 
Precisa manter relações pessoais com outros cientistas da comunidade internacional - compatriotas e estrangeiros. Cada vez mais a troca de informações se faz neste nível, por correspondência, através da remessa de manuscritos inéditos e de dados preliminares que somente serão publicados mais tarde. Vídeos e computadores são, cada vez mais, utilizados. Círculos de colegas reencontram-se em congressos, seminários, cursos e simpósios, em cujos corredores e cafés são discutidos os trabalhos correntes e as idéias ainda muito incipientes para serem apresentadas formalmente.

Deve estar capacitado para sugerir transformaçōes tecnológicas de princípios fundamentais descobertos em seu laboratório ou em outros, de que tem conhecimento preferencial.

Deve estar em condições de promover a formação de pessoal de nível avançado, não se limitando a repetir noções e informações desatualizadas constantes dos textos didáticos. Deverá transmitir experiências e não receitas não testadas por ele próprio.

Deve representar o país perante a comunidade científica internacional, integrando comitês, associaçōes, participando de reuniões e servindo de canal de comunicação especializada.

Precisa ser capaz de avaliar, de maneira independente, as ações programadas, planos, projetos e políticas, oficiais ou privados, dentro de sua área de conhecimento.

A informação científica torna-se obsoleta em pouco tempo. A taxa de sobrevivência dos artigos científicos, isto é, o período de tempo em que são citados na bibliografia é extremamente curto e somente o pesquisador ativo tem acesso à informação renovada, sabendo o que permanece válido e o que não mais se aceita.

Para que os frutos da ciência possam ser colhidos, aproveitados e consumidos é necessário estabelecer uma ponte entre o cientista, sua instituição, e os órgãos técnicos e executivos. Mas isso é uma outra história. 